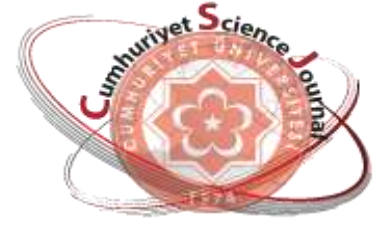

e-ISSN: 2587-246X

ISSN: 2587-2680

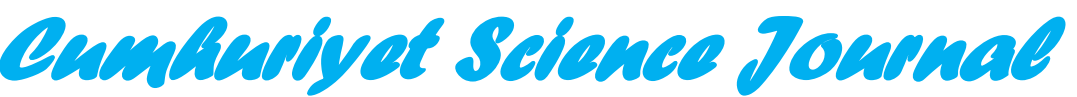

CSP

Cumhuriyet Sci. J., Vol.40-1(2019) 170-172

\title{
Biosynthesis and Characterizatıon of Silver Nanopartiiles from the Lemon Leaves Extract
}

\author{
Gönül SERDAR ${ }^{1 *}$ (D) Cansu ALBAY $Y^{1}$, Münevver SÖKMEN ${ }^{2}$ \\ ${ }^{I}$ Karadeniz Technical University, Facult of Pharmacy, Department of Analytical Chemistry, Trabzon, TURKEY \\ ${ }^{2}$ Konya Food and Agriculterl University, Faculty Engineering and Architecture, Departmen of Bioengineering, \\ Konya, TURKEY
}

\begin{abstract}
The synthesis and characterization of $\mathrm{Ag}$ nanoparticles from Citrus limonum (lemon leaves) collected the Eastern Black Sea region was investigated in this study. A household microwave system device was used for microwave extraction of lemon leaves samples. The extract was prepared by taking $10 \mathrm{~g}$ of dried lemon leaves. $10 \mathrm{~g}$ of sample was shaken in $100 \mathrm{~mL}$ of water for $90 \mathrm{~min}$ and extracted in a household microwave device at 4 minutes, $600 \mathrm{~W}$. Ag nanoparticles were synthesized that the obtained aqueous solution was taken in different volumes by mixing $1 \mathrm{mM}$ and $5 \mathrm{mM} \mathrm{AgNO}_{3}$ solution. The colloid solution was subjected to microwave in an oven 1, 3, 5, 10, 15, 20 and 30 minutes at 90,180, $360 \mathrm{~W}$. Then production of AgNPs, the mixture was watched by UV-Vis spectroscopy (Shimadzu UVP-1240 spectrophotometer) measurements at different wavelengths $(300-800 \mathrm{~nm})$ for SPR of silver nanoparticles. The transition from yellow to a dark brown, shows the synthesis of silver nanoparticles.
\end{abstract}

Keywords: Lemon leaves, Microwave Assisted Extraction, Silver nanoparticul, UV-Visible.

\section{Limon Yaprakları Ekstraktından Ag Nanopartiküllerin Biyosentezi ve}

\section{Karakterizasyonu}

\begin{abstract}
Özet. Bu çalışmada, Doğu Karadeniz Bölgesinde toplanan limon yapraklarından (Citrus limonum) Ag nanopartiküllerin sentezi ve karakterizasyonu araştırılmıştır. Limon yaprağı örneklerinin mikrodalga ekstraksiyonu için bir ev mikrodalga sistemi cihazı kullanıldı.10 g kurutulmuş limon yaprağı alınarak ekstrakt hazırlandı. Oda sıcaklığında, 10 g numune 100 mL suda 90 dakika çalkalandı ve bir ev mikrodalga cihazında, $600 \mathrm{~W}$ gücünde 4 dakika ekstrakte edildi, elde edilen sulu çözeltiden farklı hacimler alınarak $100 \mathrm{~mL}$ $\mathrm{AgNO}_{3}(1,5 \mathrm{mM})$ çözeltisi ile karıştırılır ve karışım, 90, 180, $360 \mathrm{~W}$ gücünde 1, 3, 5, 10, 15, 20 ve 30 dakika boyunca mikrodalgaya maruz bırakılarak Ag nanopartikülleri sentezlendi. Daha sonra üretilen AgNP'lerin kolloid çözeltisi, AgNP'lerin yüzey plazmon rezonansı (SPR) için UV-Vis spektroskopisi ile (Shimadzu UVP1240 spektrofotometre) farklı dalga boylarında (300 - $800 \mathrm{~nm})$ ölçümleriyle izlendi. Sarıdan koyu kahverengiye renk değişimi gümüş nanopartiküllerin sentezini gösterir.
\end{abstract}

Anahtar Kelimeler: Limon yaprakları, Mikrodalga Destekli Ekstraksiyon, Gümüş nanopartikül, UV-Görünür.

\section{INTRODUCTION}

In recent years, nanoparticle synthesis has received great attention owing to their unequalled properties and potential applications [1]. Silver nanoparticles have been synthesized by diverse physical and chemical methods [2]. When the physical methods are costly, chemical methods 
utilize toxic and hazardous chemicals which constitute significant threat to the environment and the synthesized silver nanoparticles can have reverse effects in biomedical applications due to the toxic chemicals adsorbed on their surface. The synthesis of metal nanoparticles in general and silver nanoparticles in particular exhibits a promise with potential applications in cosmetics, dermatology, pharmacology but also in catalysis and nanotechnology in general [3-5]. Especially progressive and under big expansion is the topic of green synthesis of silver nanoparticles utilizing readily available capping agents and reducing agents taken from plants and thus from renewable sources. Chemical synthesis have been shown to be simple and alternatively from green synthesis methods using either biological microorganisms or plant extracts [6].

The purpose of the work was to produce the AgNPs by exerting lemon leaves extracts which were operated in microwave assisted extraction. Microwave force is a good means for fast reduction of silver ions to silver nanoparticles at various circumtances, for example diffrerant extract volume, $\mathrm{AgNO}_{3}$ concentrations, reaction time. Characterization of silver nanoparticles was using UV-Vis spectroscopy. The reaction mixture changed brown and displayed UV-Visible spectra characteristic of silver nanoparticles.

\section{MATERIAL AND METHODS}

\subsection{Preperation of tea extract}

Fresh leaves of Citrus limonum (lemon leaves) were collected from the Eastern Black Sea region (Trabzon, Turkey). Then, the clean and fresh Citrus limonum leaves were dried in an airy environment and cut into small pieces. The extract was prepared by taking $10 \mathrm{~g}$ of dried citrus limonum leaves. $10 \mathrm{~g}$ of dried citrus limonum leaves and $100 \mathrm{~mL}$ distilled water were placed flask and then were shaken for $90 \mathrm{~min}$ at room temperature. After shaking, the flask was transferred in a household microwave device. Extraction was carried out under a controlled 600 $\mathrm{W}$ microwave power for 4 min irradiation time. After extraction, the leaf extract filtrate was obtained by filtrating the solution through Whatman filter paper no.1. The extract is used as a reducing and stabilizing agent fort the preparation of silver nanoparticles [7].

\subsection{Production and characterization of $\mathrm{AgNP}$}

Metal nanoparticles were synthesized by adding aqueous solution of $\mathrm{Ag} \mathrm{NO}_{3}$ to lemon leaf extract. $0,5,1,2 \mathrm{~mL}$ samples of Lemon leaves solution was added to $100 \mathrm{~mL}$ of $\mathrm{AgNO}_{3}$ solution $(1 \mathrm{mM}$ and $5 \mathrm{mM}$ ) in this syntheses. After the mixture was subjected to microwave in an oven $1,3,5,10$, 15,20 and 30 minutes at 90, 180, $360 \mathrm{~W}$. Subsequently the production of AgNPs colloid solution was watched by UV-Vis spectroscopy measurements at regular intervals of time. The UV spectral peaks for silver nanoparticles range from 400 to $480 \mathrm{~nm}$ [8]. Absorption spectra were measured on a Shimadzu UVP-1240 spectrophotometer. Each method was repeated three times.

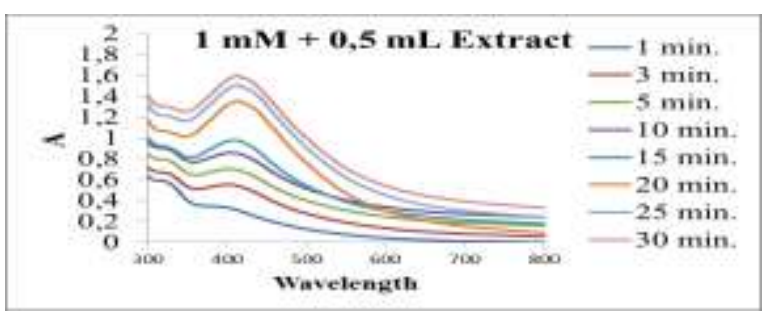

(a)

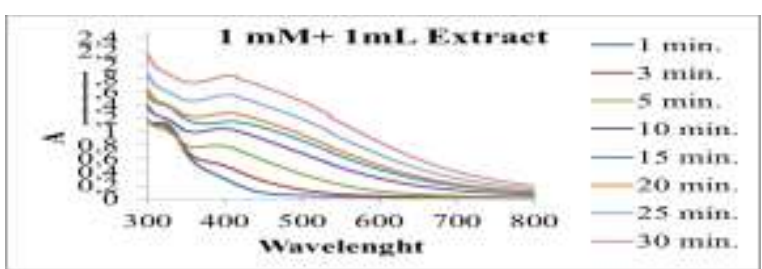

(b)

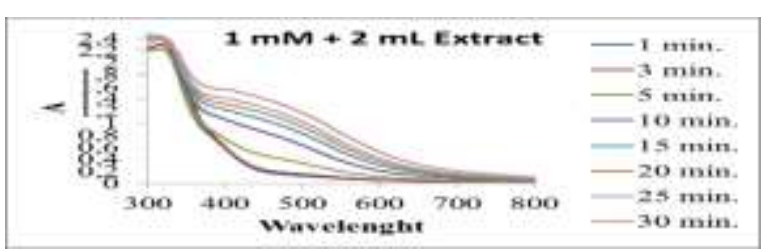

(c)

Figure 1.Uv-vis spectra of AgNPs obtained by using leaf extract of Lemon at various time ( $1 \mathrm{mM} \mathrm{AgNO}_{3}$ and a)0,5 $\mathrm{mL}$, b) $1 \mathrm{~mL} \mathrm{c)} 2 \mathrm{~mL}$ Lemon leaf extract). 


\section{RESULTS AND DISCUSSION}

Silver nitrate $\left(\mathrm{AgNO}_{3}\right)$ was used as sources of $\mathrm{Ag}+$ ion required for that the produce of silver nanoparticles. The color of the solutions turned from yellow to dark brown is strong indication of $\mathrm{Ag}$ nanoparticle formation in the solution after treatment. SPR absorption spectra of silver nanoparticles produced from $1 \mathrm{mM}$ (Fig.1) and 5 $\mathrm{mM}$ (Fig.2) $\mathrm{AgNO}_{3}$ concentration.

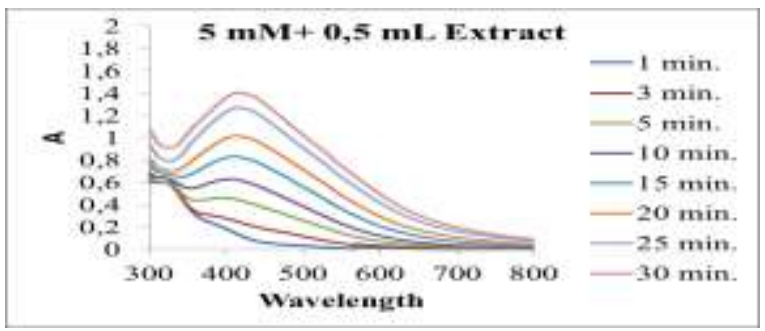

(a)

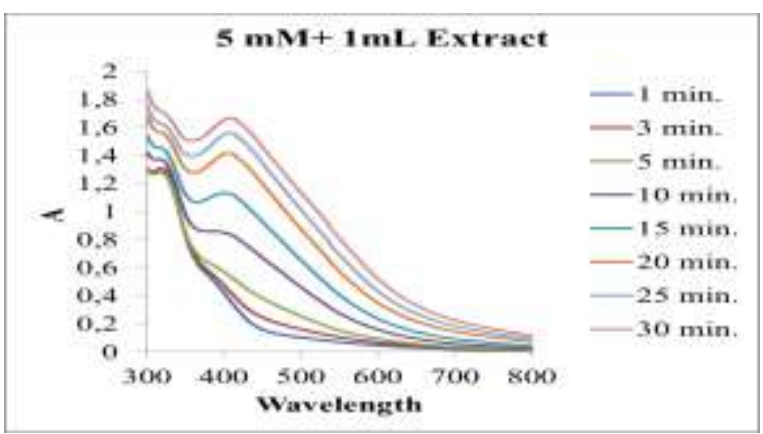

(b)

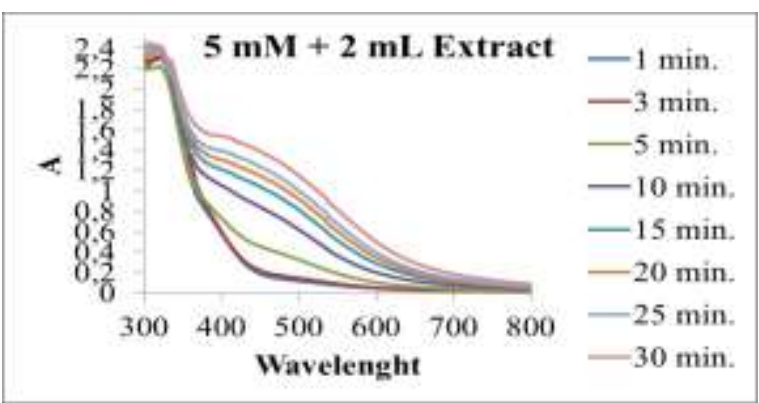

(c)

Figure 2. Uv-vis spectra of AgNPs obtained by using leaf extract of Lemon at various time ( $5 \mathrm{mM} \mathrm{AgNO}_{3}$ and a)0,5 $\mathrm{mL}, \mathrm{b}) 1 \mathrm{~mL}$ c) $2 \mathrm{~mL}$ Lemon leaf extract).

Silver nanoparticles were successfully generated by extracts with $0,5 \mathrm{~mL}$ extract volume (Fig.1a and Fig.2a). It is clear that AgNPs were successfully produced with 0,5 mLlemon leaf extract that specific resonance band surveyed around $400-460 \mathrm{~nm}$ then by 15 minutes subject.
The band reached to maximum height after 30 minutes (Fig.1 and Fig.2).

Economical, simple and fast production of AgNP was achieved. Using lemon leaf infusion extracts produce stable silver nanoparticles.

\section{REFERENCES}

[1]. Reenaa M., Menon A.S., Synthesis of silver nanoparticles from differant citrus fruit peel extracts and a comparative analysis on its antibacterial activity. Int. J.Curr. Microbiol. App. Sci., 6-7 (2017) 2358-2365

[2]. Mohapatra B., Kaintura R., Singh J., Kuriakose S., Mohapatra S., Biosynthesis of high concentration, stable aqueous dispersions of silver nanoparticles using Citrus limon extract, Adv. Matter. Lett., 6-3 (2015) 228-234.

[3]. Krutyakov Y.A., Kudrinskiy A.A., Olenin A.Y., Lisichkin G.C., Synthesis and properties of silver nanoparticles: Advances and prospects. Russian Chem. Rev., 77 (2008) 233-257.

[4]. Nath D.D., Banerjee P., Green nanotecnology- a new hope for medical biology. Environ. Toxicol. Pharmacol. 36 (2013) 997-1014.

[5]. Ravindron A., Chandran P.,Khan S.S., Biofunctionalized silver nanoparticles: Advances and prospects. Collids Surf. B:Biointerfaces, 105 (2013) 342-352.

[6]. El-Shishtawy R.M., Asiri A.M., Al-Otaibi M.M., Synthesis and spectroscopic studies of stable aqueous dispersion of silver nanoparticles. Spectrochimica Acta Part A: Molecular and Biomolecular Spectrosroscopy.79-5 (2011) 1505-1510.

[7]. Saxena A.,Tripathi R.M., Saxena A, Tripathi R.M, Zafer F, Singh P., Green synthesis of silver nanoparticles using aqueous solution of Ficus benghalensis leaf extract and characterization of their antibacterial activity, Mater Letters, 67 (2012) 91-94.

[8]. Praphulla R., Chandraprasad M., Lakshmi Y.N., Jahnavi R., Aishwarya P., Srinidhi S., Biosynthesis of silver nanoparticles using lemon extract and its antibacterial activity, Int. J. Multi.Curr., Research. 2 (2014) 165169. 